\title{
Tomasz LEGIĘDŹ1
}

\section{ROLA ORGANIZACJI I INSTYTUCJI NIEFORMALNYCH W PROCESACH TRANSFORMACJI GOSPODARCZEJ}

\begin{abstract}
Streszczenie
Wykorzystując perspektywę badawczą nowej ekonomii instytucjonalnej, w artykule przedstawiono dwie główne przyczyny trudności reformowania gospodarki w czasie transformacji od gospodarki socjalistycznej do rynkowej. Po pierwsze, przeszkoda jest działanie grup interesu, które zawsze starają się tak wpływać na proces zmian instytucjonalnych, żeby osiagać jak największe własne korzyści. Po drugie, aby uzyskać optymalnie społeczną równowagę instytucjonalna, wszyscy powinni przestrzegać ustanowionych zasad, jednakże czasami najlepszą strategia z punktu widzenia jednostek może być oszukiwanie. Zasadniczo trudno przewidzieć, kiedy społeczeństwo będzie w stanie stworzyć efektywne zasady, które większość będzie skłonna przestrzegać. Prawdopodobieństwo stworzenia efektywnego systemu instytucjonalnego jest w dużym stopniu uwarunkowane przez instytucje nieformalne. Niestety, nasza wiedza o tym, jak kształtuje się nieformalna część systemu instytucjonalnego, jest nadal dość ograniczona.
\end{abstract}

Słowa kluczowe: nowa ekonomia instytucjonalna, transformacja gospodarcza, grupy interesu, instytucje nieformalne

\section{ROLE OF INFORMAL ORGANISATIONS AND INSTITUTIONS IN ECONOMIC TRANSFORMATION}

\section{Summary}

Using the perspective of new institutional economics, the paper presents two adverse factors which affect the transition from the socialist system to a free market one. Firstly, the process of institutional change is almost always influenced by interest groups which pursue their own goals. Secondly, in order to achieve a socially optimal institutional equilibrium, everyone should abide by the established rules. Sometimes, however, deception is the best strategy from the individual point of view. It is difficult to predict when society will be able to create effective rules likely to be respected by the majority. This is largely determined by the existing informal institutions. Unfortunately, our knowledge about how to shape the informal part of the institutional system, is still quite limited.

Key words: new institutional economics, economic transition, lobby groups, informal institutions

DOI: $10.15290 /$ ose.2015.01.73.06

\section{Wstęp}

Analizując spory wokół transformacji społeczno-gospodarczej od gospodarki planowej do rynkowej, można postawić tezę, iż dyskusję zdominowała kwestia szybkości i zak-

\footnotetext{
${ }^{1}$ Dr Tomasz Legiędź - Katedra Ekonomii Rozwoju, Wydział Ekonomiczno-Socjologiczny, Uniwersytet Lódzki; e-mail: legiedz@uni.lodz.pl.
} 
resu przeprowadzanych reform. $Z$ jednej strony dowodzono konieczności szybkich reform prowadzących do jak największego urynkowienia gospodarki [Sachs, 1993; Woo, 1994; Balcerowicz, 1997], z drugiej przedstawiono argumenty za scenariuszem stopniowych reform zakładajacym szeroką interwencję państwa, która miała ograniczać negatywne skutki społeczne i w konsekwencji zwiększać wzrost i rozwój gospodarczy [Portes, 1991; Roland, 1990; McMillan, Naughton, 1992; Kołodko, 1999]. Zatem, podobnie jak w większości debat gospodarczych, starli się ze sobą zwolennicy rynku ze zwolennikami interwencji państwa. Jednakże obie ze stron sporu popełniały zazwyczaj ten sam błąd polegający na niedocenianiu albo niepełnym rozumieniu istoty i złożoności instytucjonalnych uwarunkowań gospodarki.

Początkowo, planując reformy rynkowe gospodarek krajów Europy ŚrodkowoWschodniej, nie doceniono znaczenia sfery instytucjonalnej, a zwłaszcza interakcji instytucji formalnych i nieformalnych. Trudności transformacji sprawily, że podejście instytucjonalne przyciagnęło uwagę wielu ekonomistów. Jednak opowiedzenie się za instytucjonalną analizą i reformowaniem gospodarki w zgodzie z założeniami ekonomii instytucjonalnej nie zawsze jest równoznaczne z rozumieniem instytucjonalnej zmiany i często odbiega od analizy D. C. Northa oraz innych czołowych przedstawicieli nowej ekonomii instytucjonalnej. Instytucjonalna krytyka reform często jest sprowadzana do krytyki rynku i postulatu wzmożonej ingerencji państwowej, tak jakby państwo mogło względnie swobodnie tworzyć instytucje służące rozwojowi gospodarczemu. W konsekwencji bardzo często formułuje się wytyczne dla polityki gospodarczej, zakładając, że instytucje można stosunkowo łatwo zmieniać. Zwykle pomija się problemy związane z ułomnościami państwa i tworzeniem instytucji, na które zwracają uwagę czołowi przedstawiciele nowej ekonomii instytucjonalnej. Ten sam problem ma miejsce w sytuacji, kiedy ekonomiści postulują ograniczenie interwencji państwa; tu znów pojawia się sugestia, że mechanizmy rynkowe niezależnie od kulturowego podłoża szybko prowadzą do uruchomienia procesów rozwoju gospodarczego [North, 2005; Wallis, 2011; Greif, 2006].

Proces transformacji gospodarczej w krajach postsocjalistycznych nie zależał jedynie od dobrej woli, uczciwości i mądrości sprawujących władzę z dwóch powodów. Po pierwsze, instytucje formalne wyznaczające podstawowe ramy działań gospodarczych nie powstaja jedynie jako rezultat pracy obiektywnych, nieomylnych ekspertów, ale są głównie efektem rywalizacji organizacji. Natomiast te organizacje czy też grupy interesu chcą stworzenia reguł, które będą korzystne przede wszystkim dla nich, a niekoniecznie dla całego społeczeństwa. Po drugie, instytucje formalne działają dzięki instytucjom nieformalnym. To instytucje nieformalne mogą być przyczyną tego, że w pewnych sytuacjach jednostki decydują się przestrzegać prawo, a w innych nie. Tymczasem ta część systemu instytucjonalnego jest niewrażliwa na umyślne działanie polityków, stąd proces transformacji jest bardziej rezultatem zastanych instytucji oraz przypadku, aniżeli jakości prowadzonej polityki. Celem artykułu jest przedstawienie argumentów przemawiających za powyższą tezą. 


\section{Proces zmian instytucjonalnych}

Silne państwo posiada monopol użycia siły, dzięki któremu jest w stanie zapewnić stabilność, ochronę praw własności oraz egzekwowanie umów, a tym samym obniżać koszty transakcji. Jednakże to samo państwo może wykorzystać swoją pozycje do wywłaszczenia własności lub ciemiężenia obywateli. Podejście instytucjonalne i włączenie kosztów transakcyjnych do analizy ekonomicznej jest równoznaczne z odrzuceniem walrasowskiego ujęcia rynków. W związku z tym, co jest istotne przy analizie gospodarek krajów państw transformacji, rynek niekoniecznie jest optymalnym miejscem dystrybucji wszystkich dóbr i usług. Mimo wszystko z istnienia wad rynku nie wynika, że interwencja państwa w gospodarkę będzie zawsze skuteczna. Rządy także są niedoskonałe i bardzo często, zamiast niwelować, potęgują koszty transakcji przez nadmiernie zbiurokratyzowaną administrację i oportunistyczne działanie urzędników oraz polityków. Pojawia się zatem pytanie, czy to niedoskonały rząd powinien korygować wadliwie działające rynki, czy może jednak przez deregulację i liberalizację trzeba ograniczać państwo? Odpowiedź nie jest oczywista, ponieważ jeżeli istniejący system instytucjonalny nie jest w stanie zapewnić efektywnego działania mechanizmu rynkowego, to dlaczego miałby zapewnić efektywne działanie władz państwowych.

$\mathrm{Na}$ początku należy bliżej przyjrzeć się procesowi instytucjonalnych zmian. Według Northa [North, 1990; North, 2005] oraz A. Greifa [Greif, 2006], proces zmian instytucjonalnych jest nieergodyczny, czyli uwarunkowany historycznie i nieprzewidywalny ${ }^{2}$. Impulsem do przemian może być zmiana w relacji cen, np.: czynników produkcji, kosztów informacji czy technologii lub zmiana preferencji jednostek. Źródła przemian instytucji mają charakter zarówno egzogeniczny, jak i endogeniczny, lecz to czynniki wewnętrzne, które są odzwierciedleniem działania ludzi starających się maksymalizować korzyści, są główną przyczyną przekształceń obowiązującego systemu instytucji. Kierunek zmian instytucjonalnych jest efektem wzajemnych interakcji między istniejącymi zasadami oraz ludźmi przeważnie zrzeszonymi w organizacjach. Instytucje kształtują ludzkie działanie, zaś organizacje starają się wpłynać na instytucje w celu osiagnięcia zamierzonych korzyści. System instytucjonalny składa się zarazem $z$ instytucji formalnych, jak i nieformalnych. Zasady i reguły formalne stworzone intencjonalnie przez ludzi działają dzięki instytucjom nieformalnym. Natomiast wierzenia, zwyczaje oraz tradycja, które składają się na instytucje nieformalne, stanowią zasadniczą część kognitywnych modeli jednostek. Zasady nieformalne zawarte w zwyczajach, tradycjach i kodeksie zachowania są stosunkowo nieczułe na umyślne działania człowieka, stąd cały system instytucjonalny jest wypadkowa tych celowych intencji oraz nieumyślnego efektu przekształceń matrycy instytucjonalnej. Główną przyczyna gospodarczo-społecznego zacofania jest problem $z$ takim przekształceniem systemu instytucji, żeby mógł on pozwolić dokonywać bezosobowych transakcji ekonomicznych czy politycznych, przy stosunkowo niskich kosztach transakcji. Powstały system instytucjonalny nie musi być społecznie efektywny i może istnieć w takiej formie dłuższy okres [North, 2005; Kim, 2008].

\footnotetext{
${ }^{2} \mathrm{~W}$ literaturze polskiej ten problem poruszali m.in.: M. Lissowska [Lissowska, 2008] oraz W. Morawski [Morawski, 2001].
} 


\section{Instytucje i organizacje}

Zatem jednym z głównych powodów, dlaczego nieefektywny społecznie system instytucjonalny tak trudno zmienić, jest świadome działanie organizacji. Organizacje, powołane w celu zaspokojenia pewnych potrzeb, działają na korzyść swoich założycieli, a nie dla ogólnej, społecznej satysfakcji. Starają się wykorzystać, zgodnie z możliwościami swoich członków, istniejący system instytucji [Eggertsson, 1996, s. 12; Eggertsson, 2005, s. 27; North, 1990]. North, tak jak wielu ekonomistów instytucjonalnych, przyjmuje ewolucyjny obraz organizacji, zakładając, że organizacje reagują na zmieniające się warunki i wykorzystują szanse, jakie niesie nowo pozyskana wiedza [ngram, 1998, s. 259; Nelson, Winter, 1982]. W związku z tym, że organizacje są ograniczone nie tylko przez zasady instytucjonalne, ale także przez posiadane zasoby i wiedzę, wzajemna interakcja tych wszystkich czynników będzie decydować o szansach przedsiębiorców czy polityków na maksymalizacje potencjalnych korzyści [North, 1990, s. 73]. Różne organizacje wzajemnie konkuruja aby przetrwać i zwyciężyć, dlatego są zmuszone do nieustannego inwestowania w nowe umiejętności i wiedzę. Natomiast dzięki zdobytym informacjom organizacje podejmują decyzje, które zmieniają instytucje. Proces uczenia się organizacji oraz jednostek zależy przede wszystkim od tego, jaki jest oczekiwany zysk z wiedzy, którą pozyskują. To, jakie umiejętności postrzega się za istotne, zależy jednak od otoczenia instytucjonalnego. Jak twierdzi North, jeśli obowiązujące zasady nagradzają piractwo bardziej aniżeli produkcję, ludzie starają się zostać lepszymi piratami, a nie producentami [North, 1997, s. 23]. W zależności od tego, czy instytucje zachęcające do piractwa zostaną zastapione przez zasady, które prowadzą do wzrostu produktywności, może nastapić rozwój gospodarczy.

W przypadku krajów transformacji łatwo znaleźć przykłady działań zorganizowanych grup, które w reformach gospodarczych widziały zagrożenie dla swoich interesów. Jak zauważa M. Olson [Olson, 2000, s. 160], w momencie upadku systemu komunistycznego oraz postępującej demokratyzacji do największych grup interesu w krajach transformacji należeli menedżerowie oraz pracownicy dużych przedsiębiorstw państwowych. Wcześniej organizację te były uzależnione od polityki władz centralnych i przez nie kontrolowane, jednocześnie stanowiąc podstawowe źródło dochodów państwa. Natomiast głównym celem wielu firm państwowych było zachowanie wielu przywilejów przyznanych w czasach obowiązywania zasad gospodarki realnego socjalizmu. W nowej sytuacji te najsilniejsze grupy interesu zaczęły także zabiegać o nowe subsydia. Wobec tego, że były to zasadniczo jedyne, dobrze zorganizowane organizacje w tamtym czasie, o ich względy musiały walczyć siły polityczne zarówno te związane z dotychczasowymi władzami, jak i nowe, wyłonione $z$ antykomunistycznej opozycji. To w konsekwencji mogło prowadzić do sytuacji, w której nieefektywny system instytucjonalny, pozwalający na redystrybucję dochodów do niewielkiej części społeczeństwa kosztem jego reszty, mógł trwać nadal.

Nie ulega wątpliwości, że proces transformacji był ściśle uzależniony od działania grup interesów zarówno tych powstałych jeszcze w czasach komunistycznych, jak i nowo tworzacych się w wyniku rynkowych reform. Celem przeprowadzanych reform było stworzenie nowych instytucji formalnych, będących podstawą gospodarki rynko- 
wej. Te nowe zasady naruszały interesy wielu organizacji powstałych w czasie komuniz$\mathrm{mu}$, a przede wszystkim nomenklatury. Dlatego konsekwentnie grupy te sprzeciwiały się reformom. W związku z tym w niektórych obszarach proces zmian był bardzo powolny, a tam, gdzie do reform doszło, były one rezultatem kompromisu, który niejednokrotnie wypaczał ich wcześniejszy cel, czyli poprawę efektywności gospodarki.

W tym kontekście Olson [Olson, 2000, s. 158-166] zwraca uwagę na problem z prywatyzacją w byłych krajach ZSRR, która w teorii miała szybko doprowadzić do wzrostu efektywności gospodarczej ze względu na racjonalną alokacje zasobów. W przypadku Rosji grupy interesu zrzeszające menedżerów oraz pracowników przedsiębiorstw państwowych aktywnie sprzeciwiały się prywatyzacji. Stąd na pierwszym etapie „spontanicznej prywatyzacji" proces ten polegal na przejęciu przedsiębiorstw przez pracowników, a przede wszystkim menedżerów. Efekt późniejszej prywatyzacji kuponowej był podobny - dotychczasowe władze państwowych firm nabywały akcje od swoich pracowników oraz innych Rosjan znacznie poniżej ich realnej wartości. W rezultacie tych przekształceń własnościowych nie osiagnięto większej efektywności gospodarczej, ponieważ struktura wielu przedsiębiorstw zasadniczo nie zmieniła się i nadal były one często uzależnione od pomocy państwa. Prywatyzacja w Rosji, a także w wielu innych krajach transformacji, np. na Ukrainie, utrwaliła istniejące dotychczas grupy interesu oraz stworzyła nowe, skupiające oligarchów, którzy wzbogacili się w wyniku reform³.

\section{Instytucje nieformalne a reformy}

Załamanie się systemu centralnego planowania spowodowało potrzebę stworzenia nowych instytucji gospodarki rynkowej, takich jak np. prawa własności. W wyniku reform w większości krajów socjalistycznych zaczęto tworzyć owe instytucje formalne, najczęściej na wzór zasad istniejących w krajach Europy Zachodniej. W poprzedniej części artykułu wskazano, że proces ten był uzależniony od grup interesu i w konsekwencji stworzony zestaw instytucji nie zawsze był społecznie efektywny. Nawet uchwalenie potencjalnie efektywnego systemu instytucjonalnego nie daje gwarancji efektywności, ponieważ, jak można zaobserwować na przykładzie wielu krajów postsocjalistycznych, ludzie niekoniecznie przestrzegaja nowych zasad.

Jak zauważa North [North, 1990, s. 6], instytucje formalne mogą zostać zmienione z dnia na dzień, lecz zasady nieformalne zawarte w zwyczajach i tradycjach sa znacznie bardziej nieczułe na umyślne działania reformatorów. Zasady formalne i nieformalne wzajemnie się uzupełniaja, a rzeczywista przemiana instytucji formalnych także jest długotrwała. Nawet w przypadku wystapienia rewolucji, kiedy niemalże cała matryca instytucjonalna podlega przedefiniowaniu, faktycznych powodów wystapienia tego zjawiska należy szukać w procesach, które rozpoczęły się znacznie wcześniej. W taki sposób należy między innymi postrzegać upadek systemu komunistycznego w krajach Europy

\footnotetext{
${ }^{3}$ Przykład prywatyzacji w Rosji przywołują także D. Acemoglu oraz J. A. Robinson [Acemoglu, Robinson, 2013, s. 125-128]. Wskazują oni, że ekonomiści, postulując szybką powszechna prywatyzację, nie wzięli pod uwage politycznych konsekwencji reform prowadzacych ostatecznie do odbudowy systemu autorytarnego w putinowskiej Rosji.
} 
Wschodniej. Nie był on rezultatem jednorazowego wybuchu nieposłuszeństwa obywatelskiego ani szybko podjętej decyzji rządzących tymi krajami w latach osiemdziesiątych, lecz efektem niewydolności systemu gospodarczego realnego socjalizmu oraz represji komunistycznego systemu politycznego. Zmiana środowiska instytucjonalnego jest tym wolniejsza, im bardziej są zakorzenione instytucje nieformalne i w im silniejszej kolizji pozostają one z nowymi instytucjami formalnymi. Wzajemna interakcja instytucji formalnych i nieformalnych kształtuje codzienny obraz ludzkiego życia. Rutyna, zwyczaje i zasady moralne od wieków ułatwiały współdziałanie ludzi w małych grupach. W miarę pogłębiania podziału pracy i rozwoju wymiany zwiększa się intensywność kontaktów i krąg zależności ekonomicznych i coraz większy udział przypada instytucjom formalnym, regulującym stosunki i interakcje w społeczeństwie. Dostosowanie instytucji formalnych i nieformalnych jest warunkiem stabilności, czyli równowagi instytucjonalnej, ale jak podkreśla North [North, 1990, s. 83], równowaga niekoniecznie musi oznaczać efektywność.

Według Greifa [Greif, 2006, s. 30], dany system instytucjonalny kształtuje skutecznie ludzkie zachowania wtedy, gdy ludzie wykazują naturalną skłonność do przestrzegania formalnych i nieformalnych reguł tworzących ten system. Dane instytucje wpływają na ludzkie zachowanie, jeśli ludzie wierza, że inni także postępują zgodnie z przyjętymi regułami. Właśnie w takiej sytuacji mówimy, że instytucje cechuje tendencja do samoistnego ich przestrzegania (institutions are selfenforcing). Jednak efektywna równowaga instytucjonalna i wiążący się z nią pozytywny efekt zewnętrzny są często nieosiagalne, ponieważ poszczególne jednostki boją się ryzyka, jakie łączy się z tym, że kiedy one będą przestrzegać zasad, inni uczestnicy rynku nie będą tego robić.

Problem ten można zilustrować za pomocą teorii gier. Załóżmy, że dwie jednostki: A i B dokonuja transakcji gospodarczej i istnieje potencjalnie efektywny system prawny, ale może występować problem z jego egzekwowaniem. Gra ma charakter kooperacyjny, zatem gracze mogą swobodnie porozumiewać się (w przeciwieństwie do dylematu więźnia). Tabela 1. ilustruje wypłaty, jakich mogą spodziewać się A i B, jeśli będą przestrzegać zasad lub nie. W tej grze mamy do czynienia z dwiema równowagami Nasha, jednak tylko jedna z nich daje wynik optymalny w sensie Pareto.

TABELA 1.

Macierz wypłaty

A

\begin{tabular}{|c|c|c|}
\hline & Przestrzegać & Oszukiwać \\
\hline \multirow{2}{*}{ Przestrzegać } & A: 100 & A: 75 \\
& B: 100 & B: 25 \\
\hline \multirow{2}{*}{ Oszukiwać } & A: 25 & A: $\mathbf{5 0}$ \\
& B: 75 & B: $\mathbf{5 0}$ \\
\hline
\end{tabular}

Źródło: opracowanie własne. 
Jak widać na podstawie tabeli 1., jednostki: A i B zyskują najwięcej, jeśli obie zdecydują się przestrzegać zasad (optimum w sensie Pareto), lecz ryzyko, że któraś ze stron postanowi oszukać, powoduje, że dominującą strategią może być oszukiwanie. Jeżeli gra jest powtarzana wielokrotnie, a gracze nie zmieniają się, efektywna równowaga najprawdopodobniej zostanie osiagnięta. W takiej sytuacji gracze mogą mieć do siebie wzajemne zaufanie bez potrzeby tworzenia kosztownego systemu wymuszania przestrzegania prawa. Jednakże dokonywanie transakcji jedynie ze znanymi wcześniej kontrahentami oznacza znacznie mniejszy zakres działalności. Wraz z rozszerzeniem działalności maleje zaufanie, rośnie ryzyko i koszty transakcji, a wtedy strategią dominującą staje się oszukiwanie, co prowadzi do sytuacji, w której system instytucjonalny jest wprawdzie w równowadze, ale jest to równowaga społecznie nieefektywna.

Powyższa gra ilustruje problem, który jest bardzo częsty w sytuacji reform i prób tworzenia nowych praw, tak samo w krajach transformacji, jak i w państwach słabo rozwiniętych, gdzie wysokie koszty transakcji uniemożliwiają wzrost gospodarczy. Jak pisze R. Coase [Coase, 1992, s. 716] Jeśli koszty dokonania nymiany sa miekesze niž, koryyśś, jakie niesie ze soba ta nymiana, do transakeji nie dojdrie. W krajach słabo rozwiniętych zarówno koszty, jakie musieliby ponieść kontrahenci, aby zawrzeć kontrakt, jak i później go nadzorować i egzekwować, są na tyle wysokie, że do wymiany w ogóle nie dochodzi. Brak jest instytucji, które owe koszty zmniejszyłyby do poziomu zapewniającego stronom umowy korzyści z jej podpisania. W procesie rozwoju i ewolucji w krajach rozwiniętych powstały niezbędne instytucje, które na tyle zmniejszyły koszty transakcji, by gospodarka trwale się rozwijała. W większości krajów biednych, a także w krajach transformacji u progu reform rynkowych, te instytucje jeszcze nie wykształciły się lub powstały jedynie w nieskomplikowanej podstawowej formie, dlatego spektrum dokonywanych transakcji było wąskie, zapewniając najczęściej dobrobyt jedynie niewielkiej części społeczeństwa.

Jakie czynniki mogą zatem sprawić, że powstają reguły, które tworzą efektywną, służąca rozwojowi równowagę instytucjonalna, a ludzie tych reguł przestrzegaja? Jaka nowa wiedza płynie z doświadczeń transformacji od planu do rynku? Pod wpływem popularności nowej ekonomii instytucjonalnej coraz częściej zwraca się uwagę na to, że tworzone zasady formalne muszą być tak projektowane, żeby odpowiadały istniejącym w danym społeczeństwie zasadom nieformalnym, tym samym zwiększając prawdopodobieństwo ich przestrzegania. Doświadczenia transformacji od planu do rynku wydają się potwierdzać to przekonanie. Powodzenie reform w poszczególnych krajach zależy od stopnia dostosowania nowych reguł i przyjętych strategii do historycznie ukształtowanych nawyków, zwyczajów oraz mentalności jednostek i kolektywów. Tam, gdzie przetrwały postawy indywidualistyczne i przedsiębiorczość, większe były szanse na realizację głębokich reform rynkowych. Z kolei tam, gdzie tradycja indywidualizmu była słaba i długi okres komunizmu wciąż kształtuje ludzkie postawy i myślenie, próby wprowadzania rynkowych zasad nie dają oczekiwanych rezultatów.

Przyczynę powodzenia chińskiej transformacji upatruje się w tym, że w Chińskiej Republice Ludowej wykształciły się instytucje, które miały zarówno cechy charakterystyczne dla gospodarki nakazowo-rozdzielczej, jak i rynkowej [Legiędź, 2009]. W przypadku państw Europy Środkowej i Wschodniej obrano inną strategie, budowy nowych 
instytucji w ramach tzw. terapii szokowej. Według wielu ekonomistów, w większości krajów transformacji była to zła polityka [Roland, 2000; Lin, Tsai, 2004; Lau, Qian, Roland, 2000].

Dokładnie analizując przebieg reform w Chińskiej Republice Ludowej oraz innych krajach transformacji, można stwierdzić, że we wszystkich państwach postsocjalistycznych proces zmian był wypadkową wielu zmiennych i dziełem raczej przypadku niż precyzyjnie zaplanowanej polityki. Kiedy pod koniec lat osiemdziesiatych w krajach bloku wschodniego socjalistyczna gospodarka upadała, trudno było sobie wyobrazić diametralnie inną drogę reform od tej wówczas podjętej przez większość krajów bloku socjalistycznego. Chociaż dziś pewne inne rozwiązania wydają się oczywiste, w tamtym czasie alternatywa dla szybkiego wprowadzenia rynku właściwie nie istniała. Chińska droga transformacji nie była alternatywą dla „terapii szokowej” pod koniec lat osiemdziesiatych i nie byłaby nią teraz, ponieważ uwarunkowania instytucjonalne, w których znajdowały się u progu reform Chiny i kraje Europy Wschodniej, były zgoła odmienne. Szczególnie zaś należy zwrócić uwagę na instytucje nieformalne, które tak bardzo różnią Chiny i kraje Europy Środkowej i Wschodniej. To także instytucje nieformalne wyraźnie różnią państwa Europy Środkowej oraz kraje bałtyckie od reszty krajów powstałych w wyniku rozpadu ZSRR. W tych państwach, które znajdują się w sferze kultury Zachodu, gdzie represyjny system komunistyczny obowiązywał krócej, łatwiej było stworzyć względnie efektywny system instytucjonalny. To nie przypadek, że w niektórych krajach socjalistycznych działała dobrze zorganizowana opozycja, takich jak: Polska, Czechy czy Węgry, a w większości krajów powstałych po rozpadzie ZSRR nie. Najtrwalsza i niewrażliwa na zmiany część systemu instytucjonalnego uniemożliwiała stworzenie efektywnego systemu gospodarczego, który służyłby poprawie jakości życia większości obywateli. W części państw transformacji zmiana systemu społeczno-gospodarczego była oczekiwana i pożądana przez większość obywateli, a kierunek późniejszych zmian dość oczywisty (integracja z Zachodem), w innych zmiany były w pewien sposób zaskoczeniem i przyjmowane z dużą nieufnościa.

\section{Podsumowanie}

Głębsza analiza procesu transformacji skłania do wyrażenia opinii, że zasadniczo proces reform gospodarczych jest bardziej dziełem przypadku niż racjonalnego planu. W artykule przedstawiono dwie główne przyczyny trudności reformowania gospodarki, a zwłaszcza kierowania zmianą od gospodarki socjalistycznej do rynkowej. Po pierwsze, przeszkoda jest działanie grup interesu, które zawsze staraja się tak wpływać na proces zmian instytucjonalnych, żeby osiagać jak największe własne korzyści. Zatem, w sytuacji istnienia silnych organizacji, reformy naruszające status quo mogą być albo niemożliwe do przeprowadzenia, albo ostateczny kształt polityki może dalece odbiegać od pierwotnych założeń. Warte podkreślenia jest również to, że sam proces reform może prowadzić do powstawania nowych grup interesu, które będą w stanie wykorzystać powstały ład instytucjonalny w taki sposób, iż nie będzie to społecznie efektywne. Dlatego, 
jak słusznie postuluja Acemoglu oraz Robinson [Acemoglu, Robinson, 2013], reformy gospodarcze muszą być prowadzone ze zrozumieniem ich konsekwencji politycznych.

Po drugie, aby osiagnąć optymalnie społeczną równowagę instytucjonalną, wszyscy powinni przestrzegać ustanowionych zasad. Jednakże czasami, np. ze względu na ryzyko, najlepszą strategią z punktu widzenia poszczególnych uczestników społecznej gry może być oszukiwanie. Efektywna równowaga może zostać osiagnięta, jeżeli istnieje efektywny system egzekucji istniejącego prawa. Strony transakcji mogą być same zainteresowane jego ustanowieniem, ale koszt jego stworzenia nie może być wyższy niż potencjalny zysk z przestrzegania prawa. Prawdopodobieństwo stworzenia efektywnego systemu instytucjonalnego jest w dużym stopniu uwarunkowane przez instytucje nieformalne. Niestety, nasza wiedza o tym, jak kształtuje się nieformalna część systemu instytucjonalnego, jest nadal dość ograniczona. Zasadniczo trudno przewidzieć, kiedy społeczeństwo będzie w stanie stworzyć efektywne zasady, których większość będzie skłonna przestrzegać.

\section{Literatura}

Acemoglu D., Robinson J. A. 2013 Ekonomia kontra polityka: niebespiecżne rady w kewestiach polityki ekonomicznej, „Gospodarka Narodowa”, nr 11-12.

Balcerowicz L. 1997 Sogjalizm, kapitalizm, transformacja: szkice z przetomu epok, Wydawnictwo Naukowe PWN, Warszawa.

Coase R. H. 1992 The Institutional Structure of Production, „American Economic Review”, t. 82 , no. 4.

Eggertsson T. 1996 A Note on the Economics of Institutuions, [in:] Empirical studies in institutional change, L. J. Alston, P. Eggertsson, T. Eggertsson, D. C. North (eds.), Cambridge University Press, Cambridge.

Eggertsson T. 2005 Imperfect Institutions: Possibilities and Limits of Reform, University of Michigan Press, Ann Arbor.

Greif A. 2006 Institutions and the Path to the Modern Economy: Lessons from Medieval Trade, Cambridge University Press, New York.

Ingram P. 1998 Changing the Rules: Interests, Organizations, and Institutional Change in the U.S. Hospitality Industry, [in:] The New Institutionalism in Sociology, M. C. Brinton, V. Nee (eds.), Russell Sage Foundation, New York.

Kim A. M. 2008 Learning to Be Capitalists, Oxford University Press, New York.

Kołodko G. W. 1999 Od szoku do terapii: ekonomia i polityka transformacji, Poltext, Warszawa.

Lau L. J., Qian Y., Roland G. 2000 Reform Without Losers: An Interpretation of China's DualTrack Approach to Transition, ,Journal of Political Economy”, t. 108, no. 1.

Legiędź T. 2009 Transformacja Cbińskiej Republiki Ludowej z.perspektyny nowej ekonomii instytucjonalnej, „Ekonomia - Prace Naukowe Uniwersytetu Ekonomicznego we Wrocławiu", nr 3 (74).

Lin J. Y., Tsai Y. 2004 Reform and Development in China: A New Institutional Economics Perspective, „Seoul Journal of Economics”, t. 17, no. 3. 
Lissowska M. 2008 Instytucje gospodarki rynkowej w Polsce, Wydawnictwo C. H. Beck, Warszawa.

McMillan J., B. Naughton 1992 Oxford Review of Economic Policy, „Oxford Review of Economic Policy", t. 8, no. 1.

Morawski W. 2001 Socjologia ekonomiczna: problemy, teoria, empiria, Wydawnictwo Naukowe PWN, Warszawa.

Nelson R. R., Winter S. G. 1982 An Evolutionary Theory of Economic Change, Belknap Press of Harvard University Press, Cambridge.

North D. C. 1990 Institutions, Institutional Change, and Economic Performance, Cambridge University Press, Cambridge, New York.

North D. C. 1997 The New Institutional Economics and Third World Development, [in:] The New Institutional Economics and Third World Development, J. Harriss, J. Hunter, C. M. Lewis (eds.), Routledge, London, New York.

North D. C. 2005 Understanding the Process of Economic Change, Princeton University Press, Princeton.

Olson M. 2000 Power and Prosperity: Outgrowing Communist and Capitalist Dictatorships, Basic Books, New York.

Portes R. 1991 The Path of Reform in Central and Eastern Europe: An Introduction, C. E. P. R. Discussion Papers.

Roland G. 1990 Political Economy of Sequencing Tacti cs in the Transition Period, [in:] Systematic Change and Stabilization in Eastern Europe, L. Csaba (ed.), Dartmouth, Aldershot.

Roland G. 2000 Transition and Economics: Politics, Markets, and Firms, MIT Press, London.

Sachs J. 1993 Poland's Jump to the Market Economy, MIT Press, Cambridge.

Wallis J. J. 2011 Deconstructing the dominant discourse: Chang on institutions and development, „Journal of Institutional Economics”, t. 7, nr 04, DOI: 10.1017/S1744137411000099.

Woo W. 1994 The Art of Reforming Centrally Planned Economies: Comparing China, Poland, and Russia, ,Journal of Comparative Economics”, t. 18, no. 3. 